http://dx.doi.org/10.18778/1429-3730.51.02

\title{
mgr Bartłomiej Pawlak*
}

\section{STRUKTURA WIEKU OSÓB PRACUJĄCYCH A WZROST GOSPODARCZY**}

\author{
THE EMPLOYEES'AGE STRUCTURE \\ ECONOMIC GROWTH
}

\begin{abstract}
Aging of employees is a huge and global problem in times of low birth rate. Because of decreasing number of births and extending lifetime of Polish populations this problem also applies to the Polish economy. One of the economic consequences of aging is extended time of work activity for older people. For this reason the main goal of the article was to examine the direction and influence of changes in the employees' age structure on economic growth measured by labor productivity (presented as the dynamics of real Gross Domestic Product per employee). The results of the empirical study contained in the article shows that the highest productivity of employees falls on the age of 40. It was also found that there is an optimal value for the age diversity of employees, in which labor productivity is the highest. On the basis of the obtained results, conclusions regarding the Polish economy were presented.
\end{abstract}

Keywords: work productivity, aging of the population, working people age structure, demography, economic growth

JEL classification: J14, J20, C10, C20

\footnotetext{
* Doktorant, Uniwersytet Łódzki, Wydział Ekonomiczno-Socjologiczny; absolwent studiów magisterskich - Analityka gospodarcza oraz Finanse i rachunkowość, Uniwersytet Łódzki; bartlomiejpawlak92@gmail.com

** Tekst powstał w oparciu o pracę magisterską autora.
} 


\section{Wstęp}

Zjawisko starzenia się to realny problem występujący $\mathrm{w}$ czasach niskiego przyrostu naturalnego, z którym boryka się obecnie także polskie społeczeństwo. Głównym powodem takiego stanu rzeczy jest zmniejszająca się liczba urodzeń oraz wydłużający się czas życia ludności. Jedną z konsekwencji gospodarczych starzenia się społeczeństwa stanowi konieczność wydłużonej aktywności zawodowej osób starszych. Obserwowane zjawisko było przesłanką do podjęcia analizy zjawiska w przedstawionym artykule.

Głównym celem artykułu jest ocena zależności kierunku i istotności wpływu zmiany struktury wieku osób pracujących na wzrost gospodarczy mierzony wydajnością pracy przedstawioną jako dynamika realnego Produktu Krajowego Brutto na osobę pracującą. Weryfikacji poddane zostały następujące hipotezy:

- Wplyw średniego wieku pracowników na wydajność pracy jest nieliniowy i można go opisać w postaci parabolicznej. Istnieje więc wiek optymalny, $w$ którym pracownik jest najbardziej wydajny, a po jego przekroczeniu wydajność pracy spada;

- Zróżnicowanie wieku osób pracujących wptywa nieliniowo na wzrost gospodarczy Polski. Występuje więc optymalne zróżnicowanie wieku pracowników cechujące się największa wydajnościa pracy a po jego przekroczeniu wydajność pracy spada.

Artykuł podzielony został na trzy części. Pierwsza część prezentuje wydajność pracy w ujęciu teoretycznym, ukazując spojrzenie historyczne oraz współczesne. W dalszej części poruszono kwestie konsekwencji ekonomicznych wynikających $\mathrm{z}$ postępującego procesu starzenia się ludności. Na koniec przedstawiono empiryczną analizę wpływu wieku na wydajność pracy oraz otrzymane na jej podstawie wyniki i wnioski.

W badaniu empirycznym wykorzystano modele wzrostu gospodarczego (wyrażonego jako wydajność pracy). Estymacja przeprowadzona została za pomocą Klasycznej Metody Najmniejszych Kwadratów. Dane użyte w badaniu pozyskane zostały z Głównego Urzędu Statystycznego. Są to dane o kwartalnej częstotliwości rozpoczynające się w IV kwartale 2006 roku, a kończące się na I kwartale 2016 roku. Obiektem badań jest ogół osób pracujących, określanych jako osoby w wieku 15 lat lub wyżej, które wykonywały pracę przynoszącą zarobek przynajmniej przez jedną godzinę tygodniowo. Estymacja modeli przeprowadzona została $\mathrm{z}$ wykorzystaniem oprogramowania statystycznego EViews 8. 


\section{Wydajność pracy}

\section{a) Charakterystyka wydajności pracy}

Dobrobyt każdego społeczeństwa nierozłącznie powiązany jest z efektywną oraz wydajną pracą. Już Adam Smith w swojej teorii pracy przedstawionej w dziele Badania nad natura i przyczynami bogactwa narodów zauważył, że na pracę, która jest głównym czynnikiem decydującym o długofalowym rozwoju gospo-

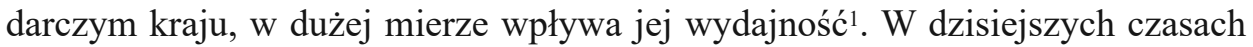
pojęcie wydajności pracy zyskało jeszcze wyższą rangę. Utrzymanie wysokiej wydajności wiąże się bowiem z większą produkcją, a co za tym idzie z większymi przychodami oraz konkurencyjnością, tak ważną w dzisiejszej gospodarce.

Wydajność pracy w dużej mierze kształtuje poziom dobrobytu społeczeństwa. Dzieje się tak, ponieważ poziom życia zależny jest przede wszystkim od zdolności produkcyjnych ludzi. Według F. Krawca pośredni związek z wydajnością ma również konsumpcja. Twierdzi on, że społeczeństwa, które potrafią wytworzyć więcej niż konsumują będą odznaczały się wyższą wydajnością pracy niż te, które konsumują więcej niż są w stanie wytworzyć2.

Powszechnie wiadomo, że rozsądny człowiek dąży do osiągnięcia celu przy jak najniższych nakładach pracy. Podobna reguła dotyczy produkcji, gdzie najważniejsza jest jak najlepsza realizacja zadania przy jak najmniejszych kosztach. Każdą pracę charakteryzuje więc efektywność, która wyraża stosunek uzyskanej produkcji do ilości nakładów potrzebnych do jej wytworzenia. Wydajność pracy jest w dużym stopniu zależna od wahań koniunktury w gospodarce. W przypadku recesji bowiem w dość szybkim tempie spada produkcja, w dłuższym okresie natomiast również i zatrudnienie. Oznacza to więc, że produktywność pracy również maleje. Odwrotnie wygląda to w przypadku wzrostu gospodarczego ${ }^{3}$.

Wydajność pracy jest jedną z tych kategorii ekonomicznych, która determinowana jest przez wiele różnych czynników współdziałających ze sobą. Dotyczą one warunków gospodarczych, naturalnych, technicznych, demograficznych czy społecznych, jednak najbardziej ogólny i podstawowy podział dzieli czynniki oddziałujące na wydajność pracy na:

- kapitał ludzki - do którego zalicza się: doświadczenie, wiedzę, wykształcenie pracowników;

- kapitał fizyczny - do którego zalicza się: urządzenia, maszyny, budynki oraz wszelkie rzeczy materialne powiązane z produkcją;

${ }^{1}$ A. Smith, Badania nad natura i przyczynami bogactwa narodów, t. 1, Wydawnictwo Naukowe PWN, Warszawa 2012, s. 33-34.

${ }^{2} \mathrm{~F}$. Krawiec, Wpływ czynników osobowych na wydajność pracy robotników w przemyśle, Państwowe Wydawnictwo Ekonomiczne, Warszawa 1971, s. 7-15.

${ }^{3}$ Produktywność jako czynnik ksztaltujący wysokość wynagrodzenia, http://ciborowski. host247.pl/wydajnosc.htm [dostęp: 25.04.2018]. 
- kapitał społeczny - do którego zalicza się: wzajemne relacje oraz zaufanie jednostek, przy pomocy których możliwe jest pomnażanie osiąganych korzyści;

- technologie - do których zalicza się: materialne oraz niematerialne aspekty produkcji powiązane $\mathrm{z}$ technologią.

Wyższa wartość każdej z wymienionych wyżej kategorii (pod warunkiem jej występowania) przekłada się z dużym prawdopodobieństwem na wyższą wydajność pracy pracowników, a co za tym idzie na wzrost produkcji

\section{b) Wydajność pracy w ujęciu historycznym}

Geneza pojęcia wydajność sięga XVIII wieku, kiedy to podczas rewolucji przemysłowej rozpoczęły się próby scharakteryzowania czynników wpływających na efektywność pracy. W ówczesnych czasach termin efektywność definiowało się jako działanie prowadzące do realizacji wcześniej wyznaczonego celu. Słownik etymologiczny Larousse'a podaje, że po raz pierwszy termin wydajność został użyty w pracy twórcy szkoły fizjokratów Quesnaya. Wtedy nie istniała jednak jedna spójna definicja wydajności. Dopiero w wieku XIX zaczęto używać terminu wydajność, którego definicja była analogiczna do znaczenia słów efektywność, skuteczność czy też sprawność. Z kolei w 1888 roku Littré zdefiniował ten termin jako „zdolność produkowania"s. Sens tego pojęcia zmieniono jednak w latach dwudziestych XX wieku. Od tego czasu wydajność zaczęto określać jako proporcję między poniesionym kosztem i osiągniętym rezultatem lub też pomiędzy wkładem a wynikiem. Lata trzydzieste przyniosły ze sobą powstanie terminu ludzkiej wydajności oznaczającego relację między sumą wkładu umiejętności, energii i inwencji człowieka, a także wszelkich kosztów przez niego poniesionych do uzyskanej przez niego satysfakcji.

Teoretycy również przez lata $\mathrm{w}$ różny sposób definiowali wydajność. W końcu XIX oraz w pierwszej połowie XX wieku powstało wiele interesujących definicji wydajności. F.W Taylor za wydajność przyjmował proporcję między aktualnie uzyskiwanymi wynikami z pracy a wynikami, które uchodziły za normę ${ }^{6}$. A. Emerson uważał natomiast, że wydajność to relacja między tym, co zostało zrobione a tym, co mogłoby być, lecz nie zostało wykonane ${ }^{7}$. A.C. Millspaugh określił wydajność jako wspólne działanie przy braku wewnętrznych konfliktów ${ }^{8}$. Z kolei Ch. I. Barnard zaproponował oddzielenie terminu efektywność, którego

${ }^{4}$ J. Penc, S. Szumpich, Ergonomia przemystowa a wydajność pracy, Instytut Wydawniczy CRZZ, Warszawa 1979, s. 12-13, 17.

${ }^{5}$ F. Krawiec, Wplyw czynników osobowych..., s. 7-8. s. $10-11$

${ }^{6}$ J. Jagas, Wydajność pracy. Uwarunkowania systemowe, Wydawnictwo TiT, Opole 1995,

${ }^{7}$ H. Drury, Scientific Management: A History and Criticism, Forgotten Books, New York 2016, s. 114-115.

${ }^{8}$ J. Jagas, Wydajność pracy..., s. 10-11. 
stopień definiował poprzez poziom osiągniętego celu od wydajności oznaczającej według niego relację między uzyskanymi wynikami a założonym wcześniej minimum?.

\section{c) Wydajność pracy wspólcześnie}

W dzisiejszych czasach zagadnienie wydajności zaczyna odgrywać większą rolę w funkcjonowaniu przedsiębiorstw a także całych gospodarek. Wiele dziedzin nauki, począwszy od humanistycznych przez ekonomiczne, a kończąc na technicznych, prowadzi badania związane z wydajności i szuka sposobów jej podniesienia. Obecnie wydajność definiuje się jako wielkość produkcji, która przypada na jednostkę wykorzystanego do jej wytworzenia czynnika produkcji. Tak więc, o wydajności pracy mówimy wtedy, gdy czynnikiem tym jest praca. Najczęściej za wyżej wspomnianą jednostkę pracy zużytą do wytworzenia czynnika produkcji przyjmuje się roboczogodzinę lub pracownika. J. Brémond oraz M. Salort definiują wydajność pracy jako ,stosunek produkcji do czasu pracy niezbędnego do jej wytworzenia"10. Z kolei niniejszy artykuł opisywać będzie wydajność pracy w odniesieniu do osób pracujących, dlatego też wyjaśniono ją poprzez wartość produkcji wytworzonej w danym okresie przypadającą na jednego pracownika. Obliczona została jako dynamika realnego PKB podzielona przez liczbę pracowników. W przypadku szybszego wzrostu PKB niż liczby pracowników mówi się o wzroście wydajności. Przyjmuje się również, że wydajność uznawana jest za miarę efektywności pracy pracownika.

\section{Wydajność pracy a wiek osób pracujących}

\section{a) Ekonomiczne następstwa starzenia się ludności}

Starzenie się ludności w dzisiejszych czasach jest zjawiskiem dynamicznie postępującym. Od kilkudziesięciu lat można zaobserwować znaczące zmiany w strukturze demograficznej Europy, jak i innych kontynentów. Dodatkowo demografowie przewidują nasilenie tego procesu w najbliższym ćwierćwieczu. Według GUS w 2030 roku odsetek osób powyżej 65. roku życia w Europie będzie wynosił 23,8\%. W Polsce natomiast spadek urodzeń rozpoczęty w 1983 roku powoduje, że w wiek reprodukcyjny wchodzą coraz mniej liczne roczniki. Według prognoz odsetek osób powyżej 65. roku życia w Polsce do 2050 roku zwiększy się o 19\% w miastach oraz $16,8 \%$ na wsi. Oznacza to, że udział osób starszych w miastach

\footnotetext{
${ }^{9}$ Ch. I. Bernard, The Functions of Executive, Harvard University Press, Cambridge 1958, s. 53.

${ }^{10}$ J. Brémond, M. Salort, Odkrywanie ekonomii, Państwowe Wydawnictwo Naukowe, Warszawa 1994, s. 179.
} 
będzie wynosił około $35 \%$, a na wsiach przekroczy $30 \%{ }^{11}$. Samo zjawisko starzenia się społeczeństwa powoduje wiele różnych następstw ekonomicznych, które mają bezpośredni wpływ na gospodarkę państwa.

Podstawowym elementem aspektu ekonomicznego powiększającej się populacji seniorów jest znalezienie źródeł pokrycia świadczeń emerytalnych dla osób z nich korzystających. Przy ciągłym wzroście liczby emerytów oraz spadku odsetka płatników składek ubezpieczeniowych w dłuższej perspektywie wyłania się możliwość załamania systemu emerytalnego. $Z$ tego też powodu w całej Europie przeprowadzane są reformy systemów emerytalnych mających na celu niedopuszczenie do takiego scenariusza ${ }^{12}$.

Inny poważny problem stanowi struktura wydatków oraz koszt utrzymania wciąż zwiększającej się grupy osób w wieku poprodukcyjnym. Z badań wynika, że większość seniorów będzie gospodarzami jednoosobowych gospodarstw domowych. Niestety, koszt utrzymania oraz egzystencji jest w nich o wiele wyższy niż w gospodarstwach wielorodzinnych. Z tego też powodu w Niemczech rozpowszechniana jest koncepcja przyznawania ulg przy budowie rodzinnych domów, w których zamieszkać mogłoby kilka generacji. To również znaczne ułatwienie dla seniorów osamotnionych lub takich, którzy nie są w stanie zadbać o siebie samych. Szacuje się, że do 2030 roku liczba osób zakwaterowanych zbiorowo wzrośnie dwukrotnie.

Dużym problemem wynikającym z wydłużania się życia ludności jest również zjawisko „wielochorobowości”, które wywołuje potrzebę istnienia zastępów wyspecjalizowanych lekarzy mogących pomóc takim osobom. Dodatkowo grupa seniorów zużywa $2 / 3$ całości leków rynku europejskiego ${ }^{13}$.

\section{b) Wiek a wydajność pracy}

Najczęściej z niskim poziomem aktywności zawodowej osób w wieku przedemerytalnym łączona jest ich zła kondycja zdrowotna. Nie jest to jednak całkowicie przekonujące rozumowanie, ponieważ w XX wieku osoby starsze pracowały relatywnie dłużej, a na emeryturę przechodziły w wieku późniejszym. Co więcej, obecnie ludzie dożywają późniejszego wieku w dobrej kondycji zdrowotnej. Warto więc odrzucić błędną koncepcję dotyczącą złego stanu zdrowia jako głównego czynnika bierności zawodowej osób starszych.

${ }^{11}$ Sytuacja demograficzna osób starszych i konsekwencje starzenia się ludności Polski $w$ świetle prognozy na lata 2014-2050, http://stat.gov.pl/download/gfx/portalinformacyjny/pl/ defaultaktualnosci/5468/18/1/1/ludnosc_w_starszym_wieku.pdf [dostęp: 25.04.2018].

12 Społeczne konsekwencje starzenia się populacji ze szczególnym uwzględnieniem zmian relacji opiekuńczych, s. 27, http://migageing.uw.edu.pl/wp-content/uploads/sites/36/2015/01/ SiM_03.pdf [dostęp 25.04.2018]

${ }^{13}$ Polska Akademia Nauk - komitet prognoz „Polska 2000 plus”, Polska w obliczu starzenia się społeczeństwa, Wydawnictwo Polskiej Akademii Nauk, Warszawa 2008, s. 17-19. 
Bez względu na wszystko oczywistością jest jednak, że starzenie systematycznie obniża sprawności życiowe, co ma bezpośrednie przełożenie na wydajność pracy. Biologia człowieka działa w taki sposób, że w okresie reprodukcyjnym osiąga on maksymalną wartość wydolności psychofizycznej, natomiast po przekroczeniu tego okresu spada ona stopniowo i przedstawia się w następujący sposób:

- w wieku 40 lat sprawność fizyczna obniża się o 10\%, z kolei w wieku 60 lat o około $40 \% \mathrm{w}$ stosunku do maksymalnego poziomu;

- wraz z przekroczeniem wieku granicznego w zakresie sprawności umysłowej pogarszają się możliwości zapamiętywania, pojawiają się utrudnienia w realizacji prac koncepcyjnych, wydłuża się proces przetwarzania informacji oraz zmniejszają się zdolności wykonywania kilku czynności jednocześnie;

- obniżenie tolerancji na pracę w ciężkich warunkach (hałas, zmiany temperatur), pracę zmianową oraz na nieregularne godziny pracy to jedne ze skutków pogarszania się zdolności adaptacyjnych organizmu wraz z wiekiem ${ }^{14}$.

Człowiek młody charakteryzuje się wysoką efektywnością działań zawodowych. Wynika to zarówno z wzrostu wydolności psychofizycznej, jak i szybkiego przyswajania wiedzy. Po osiągnięciu maksymalnego poziomu wydolności organizmu jeszcze przez pewien czas wydajność pracy danego człowieka rośnie, czego powodem jest ciągłe nabywanie nowego doświadczenia zawodowego. W pewnym wieku jednak kondycja organizmu pogarsza się na tyle, że nawet bogate doświadczenie zawodowe nie jest w stanie zahamować spadku efektywności pracy.

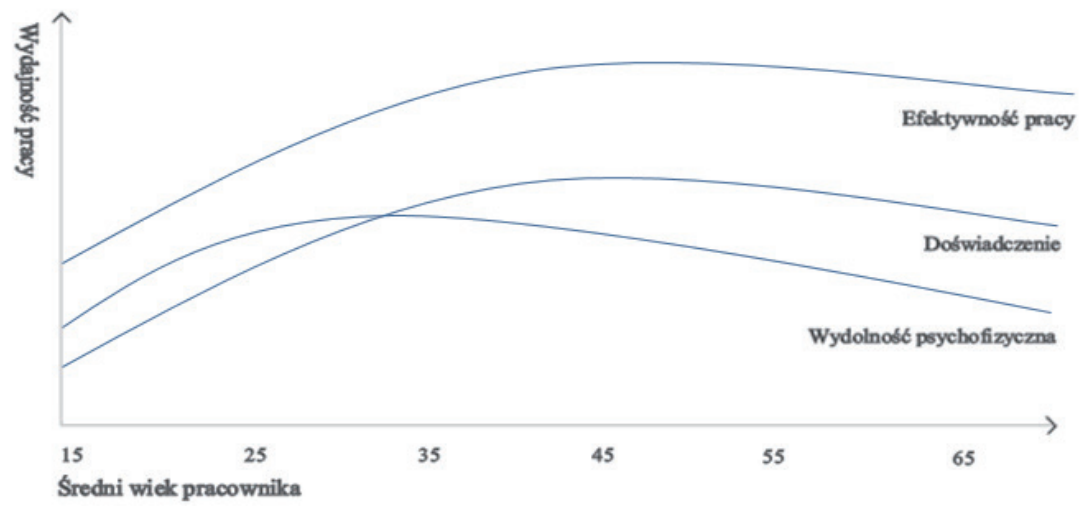

Wykres 1. Efektywność pracy, doświadczenie oraz wydajności psychofizyczna a wiek pracownika

Źródło: opracowanie własne na podstawie: Ł. Jurek, Ekonomia starzejącego się społeczeństwa, Wydawnictwo Difin, Warszawa 2012, s. 138

${ }^{14}$ A. Bortkiewicz, T. Makowiec-Dąbrowska, Wiek a zdolność do pracy, [w:] J. Kleer (red.), Konsekwencje ekonomiczne i społeczne starzenia się społeczeństwa, Wydawnictwo Polskiej Akademii Nauk, Warszawa 2008, s. 139-140. 
Warto zaznaczyć, że wykres 1, przedstawiając efektywność pracy człowieka, nie bierze pod uwagę charakterystyki wykonywanego zajęcia. Wynika to z faktu, że jedne zajęcia wymagają dużego wkładu umysłowego a drugie z kolei fizycznego. Osoba pracująca umysłowo i posiadająca duże doświadczenie zawodowe niekoniecznie sprawdzi się w typowo fizycznej pracy, gdzie trzeba przenosić ciężary i na odwrót. Trudno więc mówić o wydajności, nie precyzując, $\mathrm{z}$ jakim typem pracy mamy do czynienia.

\section{Starzenie się pracowników a ich wydajność pracy - badanie empiryczne na przykładzie Polski}

\section{a) Metodologia badania oraz przedstawienie wykorzystanego modelu}

Badanie empiryczne przeprowadzone zostało w oparciu o dwa jednorównaniowe modele ekonometryczne będące modelami wzrostu wydajności pracy. Powstały one na podstawie danych kwartalnych dla Polski pozyskanych z Głównego Urzędu Statystycznego.

Estymacja wykonana została dla okresu od IV kwartału 2006 roku do I kwartału 2016 roku (38 obserwacji) przy wykorzystaniu Klasycznej Metody Najmniejszych Kwadratów. Użycie danych kwartalnych oraz niewysoka liczba obserwacji wymuszone zostały przez ograniczoną dostępność danych dotyczących liczy osób pracujących w Polsce podzielonych ze względu na wiek.

Model wzrostu gospodarczego wyrażony jako wydajność pracy wykorzystany w badaniu ma postać:

$$
\frac{P \dot{K} B_{t}}{L_{t}}=\dot{A_{t}} f\left(\text { srwiek }_{t}, \text { zrwiek }_{t}, \text { stopainwe }_{t}, \text { inf }_{t}\right)
$$

Badany okres $\boldsymbol{t}=$ IV.2006 $-\mathbf{I} .2016$

stopainwe - stopa inwestycji,

inf - stopa inflacji,

srwiek - średni wiek osób pracujących,

zrwiek - zróżnicowanie wieku osób pracujących (mierzone współczynnikiem Giniego),

$\frac{P K^{\prime} B_{t}}{L_{t}}$-stopa wzrostu wydajności pracy przedstawiona jako dynamika PKB w cenach stałych na jednego zatrudnionego,

$\dot{A}_{t}-$ topa wzrostu łącznej produktywności czynników produkcji.

Wzrost gospodarczy uzależniono od średniego wieku oraz zróżnicowania wieku pracowników. W pierwszym modelu założony został paraboliczny wpływ średniego wieku, w drugim natomiast paraboliczny wpływ zróżnicowania wieku na wydajność pracy. W obu modelach wykorzystano takie zmienne jak: stopa 
inwestycji oraz stopa inflacji. Co więcej, w pierwotnym założeniu nieliniowy wpływ średniego wieku oraz zróżnicowania wieku miał być zawarty w jednym modelu, jednakże wysoka współliniowość występująca pomiędzy zmiennymi spowodowała, że było to niemożliwe. $Z$ tego też powodu, aby utrzymać teoretyczne połączenie pomiędzy dwoma utworzonymi modelami, postanowiono zawrzeć w nich odpowiednio:

- w modelu zawierającym nieliniowy wpływ średniego wieku pracowników - liniowy wpływ zróżnicowania wieku pracowników;

- w modelu zawierającym nieliniowy wpływ zróżnicowania wieku pracowników - liniowy wpływ średniego wieku pracowników.

Pierwszy, w którym zawarty został nieliniowy wpływ średniego wieku oraz liniowy wpływ zróżnicowania wieku pracowników:

$$
\begin{aligned}
& \left(\frac{P \dot{K} B}{L}\right)=-104+5,29 \text { srwiek }_{-\mathrm{a}}-0,0662\left(\text { srwiek }_{-\mathrm{a}}\right)^{2}+0,137 \text { stopainwe }+ \\
& \begin{array}{llll}
-2,58 & 2,69 & -2,73 & 20,2
\end{array} \\
& -3,89 \text { zrwiek }_{-\mathbf{3}}-0,36 \mathbf{3 i n f} f_{-\mathbf{3}} \\
& -2,13 \quad-4,55 \\
& \text { Badany okres } t=\text { IV. } 2006-\text { I. } 2016 \\
& \mathrm{R}^{2}=0,939 \quad \mathrm{DW}=1,72 \quad \mathrm{~S}_{\mathrm{e}}=0,0257 \quad \mathrm{~J}-\mathrm{B}=1,57 \quad \mathrm{~B}-\mathrm{P}=2,03 \quad \mathrm{LM}_{4 \mathrm{lag}}=2,51
\end{aligned}
$$

Drugi, w którym ujęty został nieliniowy wpływ zróżnicowania wieku oraz liniowy wpływ średniego wieku pracowników:

$$
\begin{aligned}
& \left(\frac{P \dot{K} B}{L}\right)=17,9 \text { zrwiek }_{-\mathbf{3}}-27,8\left(\text { zrwiek }_{-\mathbf{z}}\right)^{\mathbf{2}}+0,138 \text { stopainwe }-0,0691 \text { srwiek }_{-\mathbf{3}}+ \\
& 3,97 \\
& -4,14 \\
& 18,5 \\
& -3,92 \\
& -0,260 \text { inf } \\
& -3,43
\end{aligned}
$$

Badany okres $t=$ IV. $2006-$ I. 2016

$$
\mathrm{R}^{2}=0,923 \quad \mathrm{DW}=1,34 \quad \mathrm{Se}_{\mathrm{e}}=0,0285 \quad \mathrm{~J}-\mathrm{B}=4,36 \quad \mathrm{~B}-\mathrm{P}=0,861 \quad \mathrm{LM}_{4 \mathrm{lag}}=2,57
$$

Dodatkowo postanowiono porównać powyższe modele do najprostszego liniowego modelu:

$$
\begin{aligned}
& \left(\frac{P \dot{K} B}{L}\right)=5,76-0,0727 \text { srwiek }_{-\mathbf{3}}-0,702 \text { zrwiek }_{-\mathbf{3}}+0,139 \text { stopainwe + } \\
& 4,19 \\
& -3,97 \\
& -4,48 \\
& 18,5 \\
& -0,250 \text { inf } \\
& -3,32
\end{aligned}
$$

Badany okres $t=$ IV. $2006-$ I. 2016

$$
\mathrm{R}^{2}=0,923 \quad \mathrm{DW}=1,34 \quad \mathrm{~S}_{\mathrm{e}}=0,0284 \quad \mathrm{~J}-\mathrm{B}=4,52 \quad \mathrm{~B}-\mathrm{P}=1,023 \quad \mathrm{LM}_{4 \mathrm{lag}}=2,57
$$


Przy oszacowaniu powyższych modeli wykorzystane zostały kwartalne dane statystyczne dla Polski w okresie IV kwartał 2006 roku-I kwartał 2016 roku. $\mathrm{W}$ powyższych trzech modelach stopa wzrostu wydajności pracy objaśniona została przez stopę inflacji, stopę inwestycji, średnik wiek oraz zróżnicowanie wieku osób pracujących. Warto również zaznaczyć, że liniowy model 4 utworzony został w celu porównania kierunku zależności pomiędzy średnim wiekiem a wydajnością pracy oraz zróżnicowaniem wieku a wydajnością pracy osób pracujących.

Wszystkie znaki ocen parametrów strukturalnych zawarte w modelach 2, 3 oraz 4 okazały się zgodne z intuicją i teorią ekonomii. Co więcej, wszystkie zmienne występujące w tych modelach mają istotny wpływ na wydajność pracy. W każdym modelu współczynnik determinacji $\mathrm{R}^{2}$ wskazuje, że całkowita dynamika wzrostu wydajności została w ponad $92 \%$ wyjaśniona przez zmienne objaśniające. Wartość średniego błędu w każdym modelu przekroczyła 0,025 , co informuje o znaczącym odchylaniu się wartości empirycznych od teoretycznych modelu (w stosunku do średniej wartości zmiennej objaśnianej). Wysokie wahania są w głównej mierze spowodowane przez użycie danych nieodsezonowanych. W każdym z modeli test Durbina-Watsona nie daje odpowiedzi na temat występowania autokorelacji składnika losowego, jednak test Breuscha-Godfreya wskazuje na brak autokorelacji, ponieważ nie ma podstaw do odrzucenia hipotezy zerowej. Nie występuje również heteroskedastyczność, ponieważ wynik testu Breuscha-Pagana nie daje podstaw do odrzucenia hipotezy zerowej mówiącej o równości wariancji składników losowych. Z kolei test Jarque-Bera potwierdza rozkład normalny składnika losowego we wszystkich modelach.

\section{b) Optymalny wiek pracownika}

Wyniki estymacji modelu 2 potwierdziły kierunek oddziaływania oraz umożliwiły ustalenie optymalnej wartości średniego wieku pracownika dla dynamiki wydajności pracy. Wpływ średniego wieku na wydajność pracy wyznacza następującą funkcja kwadratowa:

$$
\left(\frac{P \dot{K} B}{L}\right)=-0,0662\left(\text { srwiek }_{-\mathrm{a}}\right)^{2}+5,29 \text { srwiek }_{-\mathrm{a}}
$$

Zbadanie przebiegu powyższej funkcji prowadzi do szeregu wniosków. Potwierdzona została hipoteza o parabolicznym - nieliniowym wpływie średniego wieku na wydajność pracy oraz hipoteza o występowaniu optymalnego wieku pracownika, przy którym średnio osiągają oni maksimum swojej wydajności. Od początku pracy zawodowej wydajność człowieka wraz z wiekiem stopniowo wzrasta. Zjawisko to występuje aż do około 40. roku życia, kiedy osiągnięte zostaje maksimum wydajności. Wiek ten nazywamy optymalnym. Dalej wydajność pracy wraz z kolejnymi latami życia zaczyna maleć coraz szybciej. Porównując maksymalną 
wydajność pracownika osiąganą w okolicach 40. roku życia z osobą młodą ${ }^{15}-20$ lat oraz starszą ${ }^{16}$ - 65 lat, można zaobserwować znaczącą różnicę. Pracownik w wieku 20 lat jest o prawie 25\% mniej wydajny niż osoba w wieku optymalnym, z kolei 65-letni pracownik cechuje się wydajnością mniejszą o około 39\% (wykres 2).

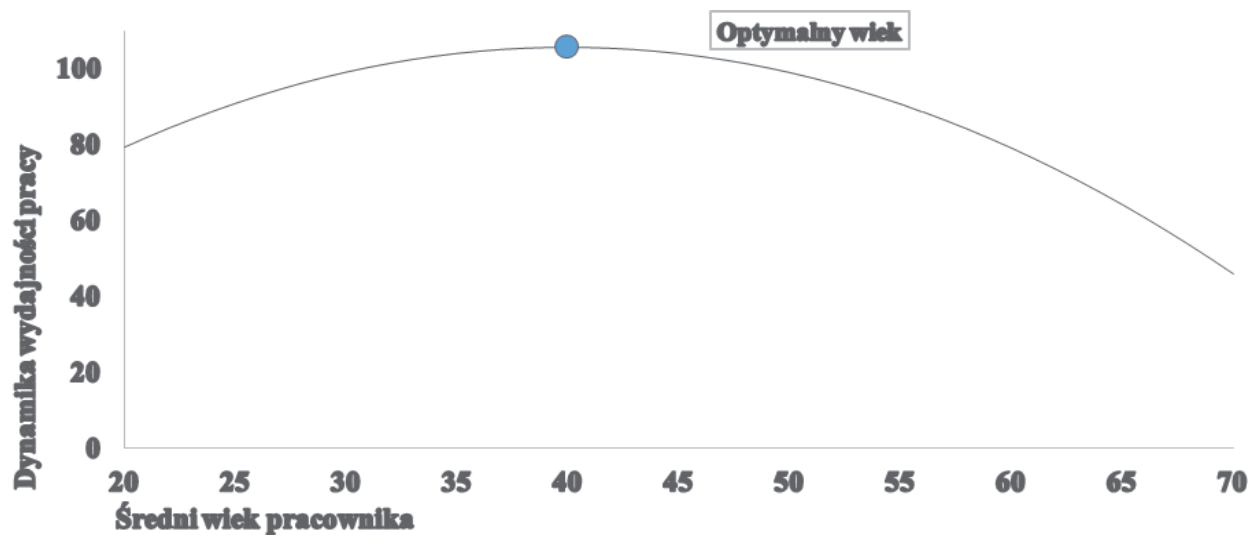

Wykres 2. Nieliniowy wpływ średniego wieku na wydajność pracy

Źródło: opracowanie własne

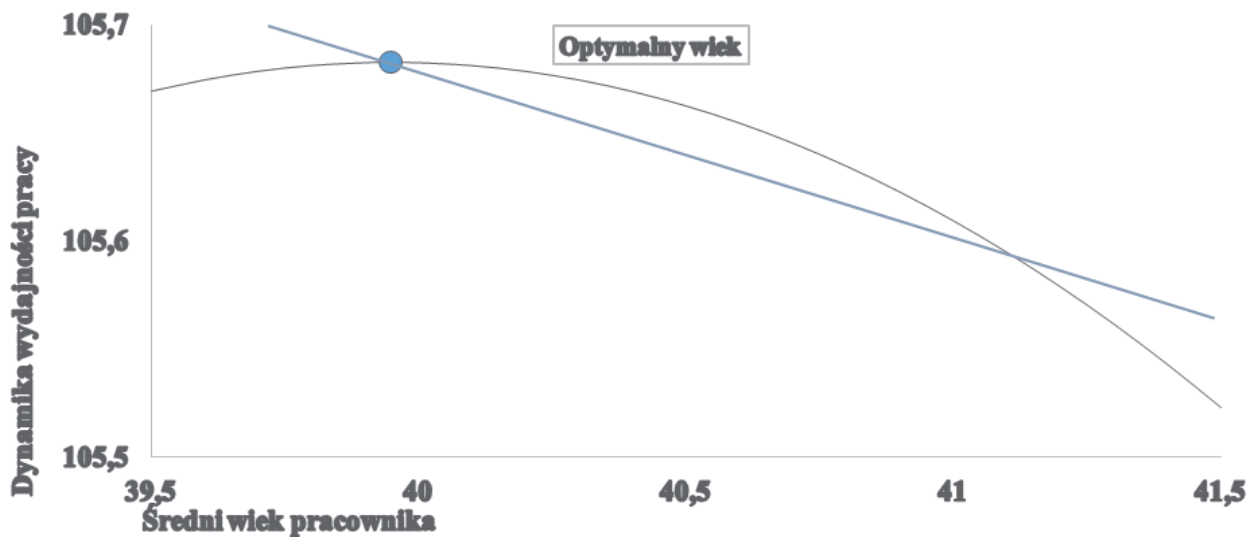

Wykres 3. Nieliniowy (czarny) oraz liniowy - model 4 (niebieski) wpływ średniego wieku na wydajność pracy (w odniesieniu do wartości obserwowanych w okresie IV kwartal 2006 - I kwartal 2016)

Źródło: opracowanie własne

${ }^{15}$ Dla uproszczenia w dalszej części pracy za pracowników młodych uznawane będą osoby w wieku 40 lat i poniżej.

${ }^{16}$ Dla uproszczenia w dalszej części artykułu za pracowników starych uznawane będą osoby w wieku 40 lat i powyżej. 
Otrzymany optymalny średni wiek przypadający na około 40 rok życia (wykres 2) jest wynikiem zbliżonym do rezultatu z badania Ch. Grunda i N. Westergaard-Nielsena, gdzie optymalny wiek pracownika przypadł na 37. rok życia. Przytoczone badanie przeprowadzono na podstawie danych dotyczących rynku pracy Danii z lat 1980-1998. Legalną pracę w Danii rozpocząć mogą osoby, które skończyły 18. rok życia ${ }^{17}$. Z kolei wiek emerytalny w tym kraju ustalony został na 65 lat dla obu płci18. Warto również zaznaczyć, że wynik dotyczący optymalnego wieku pracowników otrzymany w niniejszej pracy wydaje się prawdopodobny z punktu widzenia autora oraz ogólnego przekonania panującego w społeczeństwie ${ }^{19}$. W ostatnim stuleciu długość życia ludzi znacząco się wydłużyła, a bezpieczeństwo pracy uległo poprawie. Dlatego też w dzisiejszych czasach przeciętna pracująca osoba cieszy się lepszym zdrowiem i ma więcej sił oraz dobrego samopoczucia, często pomimo cięższej na ogół pracy. Z tego też powodu optymalny wiek pracownika około 40 lat, gdy przypada największa wydajność pracy powstała z połączenia sił witalnych oraz doświadczenia zawodowego, nie powinien być zaskoczeniem ${ }^{20}$.

Badanie pozwala zaobserwować ujemny kierunek oddziaływania średniego wieku na wydajność pracy. Po przekroczeniu 40. roku życia wydajność pracy stopniowo maleje. Ponadto zważywszy na wartości średniego wieku występujące w danych statystycznych, które przyjmuje wartości w przedziale 39-42 lat, można zaobserwować spadek wydajności pracy pracowników. Obrazuje to również liniowy wykres oddziaływania średniego wieku na wydajność pracy (wykres 3) uzyskany na podstawie estymacji modelu 4. Co więcej, aktualnie obserwowany trend starzenia się społeczeństwa powoduje, że średni wiek osób pracujących z roku na rok będzie wzrastał, co przełoży się na spowolnienie dynamiki wydajności pracy.

\section{c) Zróżnicowanie wieku pracowników}

Kolejnym analizowanym zagadnieniem jest wpływ zróżnicowania wieku pracowników na wydajność pracy. Na podstawie modelu 3 utworzona została funkcja:

${ }^{17}$ Legal Working Age - Denmark, http://arbejdstilsynet.dk/da/regler/bekendtgorelser/u/samunges-arbejde-239 [dostęp: 26.04.2018].

${ }_{18}$ Old-age Pension Systems in the Nordic Countries, https://norden.diva-portal.org/smash/get/ diva2:968720/FULLTEXT01.pdf [dostęp: 26.04.2018].

${ }^{19}$ D. Bloom, W. Lutz, A. Prskawetz, Population Aging, Human Capital Accumulation and Productivity Growth, The Population Council, New York 2008, s. 191-203.

${ }^{20}$ V. Skirbekk, Age and Individual Productivity: A Literature Survey, ,Max Planck Institute for Demographic Research Working Paper" 2003, nr 23, s. 10-15. 


$$
\left(\frac{P \dot{K} B}{L}\right)=-27,8\left(\text { zrwiek }_{-\mathbf{3}}\right)^{2}+17,9 \text { rrwiek }_{-3}
$$

Ujemna wartość parametru stojącego przy zmiennej podniesionej do kwadratu implikuje istnienie maksimum funkcji. Wykonana estymacja sugeruje, że znajduje się ono w miejscu, gdzie współczynnik Giniego obrazujący zróżnicowanie wieku pracowników osiąga wartość 0,32 . Znając uzyskany wcześniej optymalny średni wiek pracownika wynoszący 40 lat oraz wykorzystując wzór na współczynnik Giniego, można przypuszczać, że optymalne zróżnicowanie osób pracujących powinno wynosić około 26 lat. Wynik ten budzi jednak wątpliwości. Z tego też powodu w badaniu zróżnicowania wieku większość uwagi poświęcona zostanie kierunkowi wpływu zróżnicowania wieku na wydajność pracy oraz wynikającym z tego konsekwencjom. Tak więc, analizując przebieg paraboli na wykresie $4 \mathrm{w}$ miejscu danych empirycznych (użytych w badaniu) oscylujących w przedziale 0,43-0,46 (34-37 lat) wyraźnie zaobserwować można spadek wydajności pracy przy wzroście zróżnicowania wieku wyrażonego przez współczynnik Giniego (czyli opadające ramię paraboli - zróżnicowanie wieku jest zbyt duże). Potwierdzona została więc hipoteza o nieliniowym wpływie zróżnicowania wieku na wydajność pracy oraz o występowaniu optymalnego zróżnicowania wieku pracowników pozwalającego na osiągnięcie najwyższej wydajności pracy.

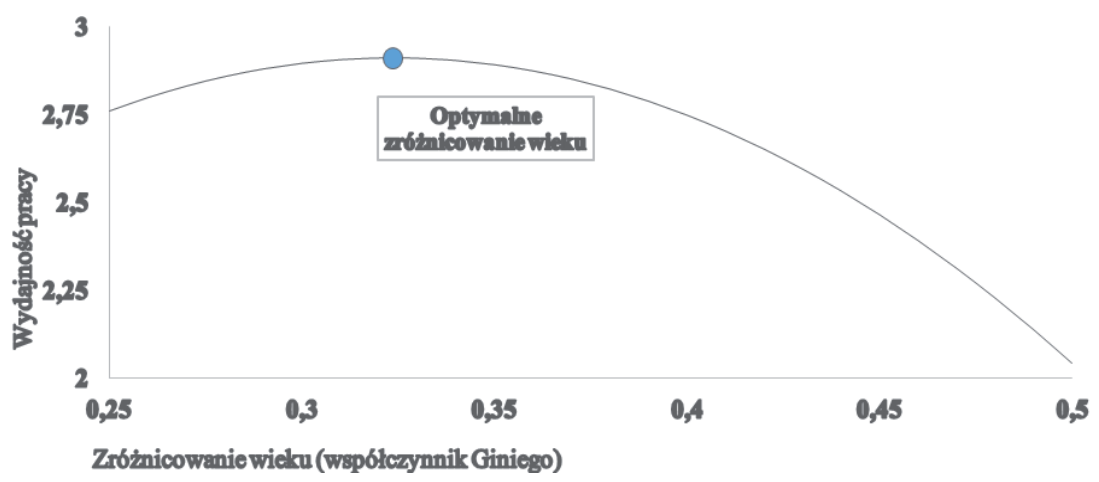

Wykres 4. Nieliniowy wpływ zróżnicowania wieku (współczynnik Giniego) na wydajność pracy Źródło: opracowanie własne 


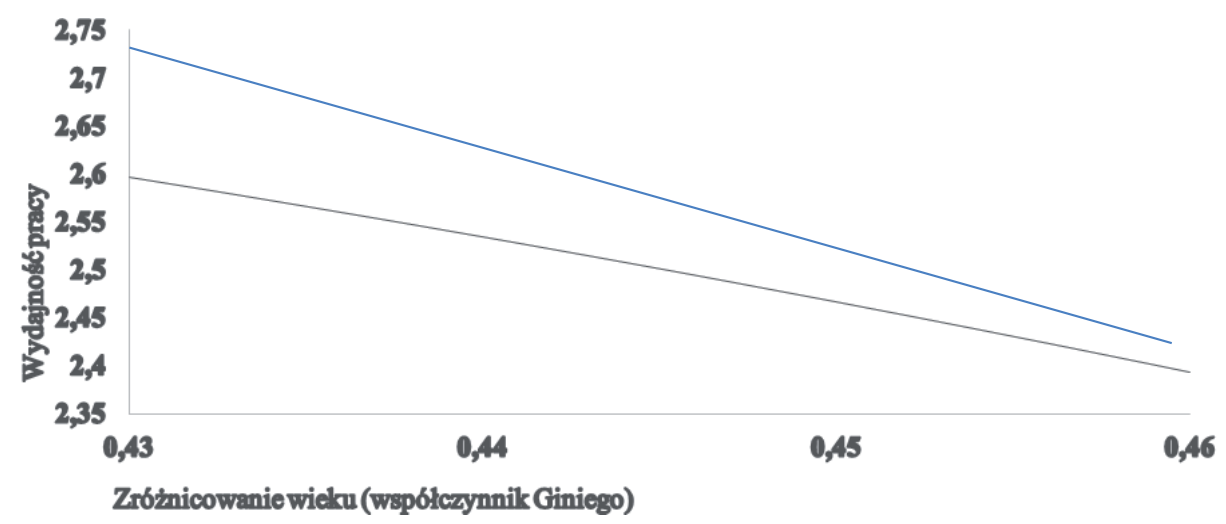

Wykres 5. Nieliniowy (czarny) oraz liniowy - model 4 (niebieski) wpływ zróżnicowania wieku (współczynnik Giniego) na wydajność pracy (w odniesieniu do wartości obserwowanych w okresie IV kwartal 2006 - I kwartał 2016)

Źródło: opracowanie własne

Negatywny kierunek oddziaływania zróżnicowania wieku na wydajność pracy potwierdza również liniowy model 4 , gdzie parametr przy zmiennej zrwiek ma znak ujemny. Na wykresie 5 obrazującym liniowe oddziaływanie zróżnicowania wieku na wydajność pracy wyraźnie zaobserwować można spadek wydajności pracy przy wzroście zróżnicowania wieku. Uzyskane wyniki, zarówno z modelu nieliniowego, jak i liniowego, wskazują na zbyt duże zróżnicowanie wieku wśród pracowników w Polsce. Otrzymane rezultaty wydają się zgodne z intuicją oraz realiami panującymi na rynku pracy. Mając na uwadze wiek 40 lat, w którym człowiek osiąga maksimum swojej wydajności, oraz fakt, że występuje zbyt duża rozbieżność wieku pracowników, można dojść do wniosku, że wśród osób pracujących jest wciąż zbyt dużo osób starszych w stosunku do młodych.

Wydaje się, że w Polsce wciąż wiele stanowisk, gdzie młodzi pracownicy sprawdziliby się lepiej zajmowanych jest przez osoby starsze. Oczywiście, nie można zupełnie wyeliminować starszych pracowników, którzy zazwyczaj posiadają bogate pracownicze doświadczenie, charakteryzują się zaawansowanymi oraz wypracowanymi przez lata umiejętnościami, a także obszerną znajomością operacyjną i organizacyjną miejsca pracy. Ponadto osoby starsze stażem najczęściej koordynują działanie całego zespołu, szkolą go, pomagają i pilnują, aby nikt nie popełniał błędów ${ }^{21}$. Prawdopodobnie jednak w większości branż zastąpienie starszych pracowników młodymi skutkowałoby znacznym wzrostem wydajno-

${ }^{21}$ Młodzi na rynku pracy pod lupa, http://www.efl.pl/wp-content/uploads/2016/08/EFL_MLODZI_PRACA_RAPORT_www.pdf [dostęp: 26.04.2018]. 
ści pracy, a dodatkowo pozwoliłoby zrealizować ambicje wielu młodym osobom chcącym się rozwijać. Warto również zaznaczyć, że osoby młode z racji swojego wieku są w stanie pracować dłużej oraz bardziej intensywnie ${ }^{22}$. Ponadto ich niezaprzeczalną zaletą jest kreatywność i świeże spojrzenie na pracę. Potrafią one dostrzec oraz zaproponować rozwiązania, które mogą znacznie usprawnić wykonywaną pracę, zwiększając tym samym jej efektywność. Dodatkowo osoby młode szybciej się uczą i przystosowują do aktualnie panujących trendów, co jest szczególnie ważne w branżach informatycznych oraz technologicznych ${ }^{23}$.

\section{d) Podsumowanie wyników}

Otrzymane wyniki potwierdzają, że aby osiągnąć wyższą wydajność pracy, należy zmniejszyć średni wiek oraz zróżnicowanie wieku pracowników w Polsce. Cel ten osiągnąć można poprzez zwiększenie liczby młodszych pracowników oraz redukcję liczby starszych. Oczywiście, zarówno pracownicy młodzi, jak i starzy mają swoje niezaprzeczalne zalety i wady. Warto jednak zauważyć, że zespół pracowników, w którym przeważają osoby starsze nie jest w stanie (jak wydaje się wynikać z modelu 3 oraz funkcji 6) osiągnąć maksimum wydajności pracy. Uzyskane wyniki mogą stanowić jeden z argumentów na rzecz obniżenia wieku emerytalnego. Powodem tego jest fakt, że pracownicy w starszym wieku charakteryzują się rutyną w działaniu, mają mniej sił i szybciej się męczą. Odwrotne cechy opisują ludzi młodych, którzy są chętni do pracy, mają mnóstwo pomysłów oraz sił witalnych. $Z$ tego też powodu wśród zatrudnionych grupa osób młodych wiekowo powinna być liczniejsza i przeważać nad grupą osób starszych (z zachowaniem optymalnego średniego wieku ok. 40 lat oraz optymalnego zróżnicowania wieku). Niestety, aktualnie w Polsce wciąż występuje bardzo duży odsetek pracowników w starszym wieku. Co więcej, odsetek ten w przyszłości będzie rósł przede wszystkim z powodu szybkiego starzenia się społeczeństwa oraz dłuższego trwania życia ludzkiego. Taki stan rzeczy powoduje oraz będzie powodował sytuacje, w której osoby starsze wykonują pracę, którą pracownicy młodsi wykonaliby o wiele efektywniej i wydajniej. Wnioskować można więc, że korzystne byłoby utworzenie nowych miejsc pracy oraz prowadzenie szeroko zakrojonej polityki aktywizacji zawodowej dla osób młodych. Ponadto warto, aby pracodawcy zdawali sobie sprawę z optymalnego zróżnicowania wieku wśród osób zatrudnionych - pozwoli to na zwiększenie wydajności pracy i przełoży się na wzrost gospodarczy ${ }^{24}$.

${ }^{22}$ Why Businesses Should Recruit Young People, http://dera.ioe.ac.uk/13758/1/whybusinesses-should-recruit-young-people.pdf [dostęp: 26.04.2018].

${ }^{23}$ R. Ciutiene, R. Railaite, Challenges of Managing an Ageing Workforce, „Engineering Economics" 2015, nr 4, s. 391-397.

${ }^{24}$ G. Dimian, B. Ileanu, M. Aceleanu, Aging and Economic Competitiveness in the Core of „North Euro-Zone”, „Engineering Economics” 2016, nr 3, s. 260-261. 


\section{Zakończenie}

Głównym celem niniejszego artykułu było ukazanie wpływu starzenia się pracowników w Polsce na wydajność ich pracy (dynamikę realnego PKB przypadającego na zatrudnionego). Zbadany został zarówno aspekt średniego wieku, jak i jego zróżnicowania. Analizy dokonano za pomocą modelu wzrostu estymowanego Klasyczną Metodą Najmniejszych Kwadratów.

Hipotezy dotyczące średniego wieku zostały potwierdzone. Wykazano nieliniowy wpływ średniego wieku pracowników na wydajność pracy, który można przedstawić w postaci parabolicznej. Wykazano również, że istnieje wiek optymalny przypadający na 40. rok życia pracownika, w którym osoba pracująca osiąga średnio maksimum swojej wydajności pracy, a po przekroczeniu tej wartości granicznej jej wydajność pracy parabolicznie spada.

Co więcej, potwierdzona została paraboliczna zależność między zróżnicowaniem wieku pracowników a wydajnością pracy. Ustalono również, że istnieje optymalna wartość zróżnicowania wieku pracowników, w którym wydajność pracy jest najwyższa. Na podstawie uzyskanych wyników optymalny punkt przypadł w miejscu występowania wartości 0,32 współczynnika Giniego. Rezultat ten przy założeniu optymalnego średniego wieku przypadającego na 40. rok życia pozwolił przypuszczać, że zróżnicowanie powinno wynosić około 26 lat. Otrzymana wartość wydała się autorowi wątpliwa - była znacząco niższa od obserwowanych wartości. $Z$ tego też powodu główna uwaga skupiona została na kierunku zależności, która okazała się następująca - wraz ze wzrostem zróżnicowania wieku pracowników wydajność pracy spada.

Biorąc pod uwagę weryfikowane hipotezy dotyczące optymalnej wartości średniego wieku i zróżnicowania wieku, a także te odnoszące się do nieliniowej zależności między średnim wiekiem a wydajnością pracy oraz zróżnicowaniem wieku a wydajnością pracy, wnioskować można, że wyższą wydajność pracy charakteryzują się osoby młode. Przypuszczać można więc, że zastępowanie starszych pracowników młodymi będzie skutkować zwiększeniem wydajności pracy. Oczywiście, zależność ta nie będzie prawdziwa w każdym przypadku, wszystko zależy bowiem od rodzaju wykonywanej pracy oraz potrzebnych do niej umiejętności i predyspozycji. Co więcej, aby osiągnąć wyższą wydajność pracy, ważne jest również zmniejszenie zróżnicowania wieku pracowników. Otrzymane rezultaty wydają się spójne i logiczne. Młodsi pracownicy mają więcej sił witalnych, świeżych pomysłów oraz zapału do pracy. Z kolei starszych pracowników niejednokrotnie cechuje rutyna oraz brak zaangażowania, czego najczęstszym powodem jest zmęczenie oraz pogarszający się stan zdrowia. Wszystko to zarówno 
u młodych, jak i starszych pracowników przekłada się na wydajność pracy a następnie na ogólny wzrost gospodarczy ${ }^{25}$.

$\mathrm{Na}$ przyszłość zaproponować można rozszerzenie przeprowadzonego badania. Najbardziej wartościowa wydawałaby się implementacja zmiennej dotyczącej długości trwania życia. Niestety, istnieje obawa, że mogłaby być ona silnie skorelowana ze zmienną dotyczącą średniego wieku, a tym samym prowadzić do współliniowości.

Badanie można także rozszerzyć na inne kraje Unii Europejskiej, a następnie porównać uzyskane rezultaty z wynikami otrzymanymi dla Polski.

Alternatywą jest również wykonanie podobnego badania dotyczącego wydajności pracy w skali mikro - przykładowo na podstawie danych przedsiębiorstw produkcyjnych. W tym wypadku (w zależności od dostępnych danych) najciekawsze wydaje się sprawdzenie charakterystyki wydajności pracy w podziale na płeć, a tym samym ustalenie wieku, w którym kolejno dla mężczyzn oraz kobiet przypada najwyższy poziom wydajności pracy. Warte zbadania jest również zagadnienie zróżnicowania wydajności pracy w zależności od wykształcenia oraz wynagrodzenia pracowników.

\section{Bibliografia}

Bernard Ch. I., The Functions of Executive, Harvard University Press, Cambridge 1958.

Bloom D.E., Canning D., Fink G., Implication of Population Ageing for Economic Growth, „Oxford Review of Economic Policy" 2010, nr 4, s. 583-612.

Bloom D., Lutz W., Prskawetz A., Population Aging, Human Capital Accumulation and Productivity Growth, The Population Council, New York 2008.

Bortkiewicz A., Makowiec-Dąbrowska T., Wiek a zdolność do pracy, [w:] Kleer J. (red.), Konsekwencje ekonomiczne i społeczne starzenia się społeczeństwa, Wydawnictwo Polskiej Akademii Nauk, Warszawa 2008, s. 111-144.

Brémond J., Salort M., Odkrywanie ekonomii, Wydawnictwo Naukowe PWN, Warszawa 1994.

Ciutiene R., Railaite R., Challenges of Managing an Ageing Workforce, „Engineering Economics” 2015, nr 4, s. 39-397.

Dimian G., Ileanu B., Aceleanu M., Aging and Economic Competitiveness in the Core of „North Euro-Zone”, „Engineering Economics” 2016, nr 3, s. 253-264.

Drury H., Scientific Management: A History and Criticism, Forgotten Books, New York 2016.

Jagas J., Wydajność pracy. Uwarunkowania systemowe, Wydawnictwo TiT, Opole 1995.

Krawiec F., Wpływ czynników osobowych na wydajność pracy robotników w przemyśle, Państwowe Wydawnictwo Ekonomiczne, Warszawa 1971.

Old-age Pension Systems in the Nordic Countries, https://norden.diva-portal.org/smash/get/ diva2:968720/FULLTEXT01.pdf [dostęp: 27.04.2018].

${ }^{25}$ D.E. Bloom, D. Canning, G. Fink, Implication of population ageing for economic growth, „Oxford Review of Economic Policy” 2010, nr 4, s. 583-590. 
Penc J., Szumpich S., Ergonomia przemystowa a wydajność pracy, Instytut Wydawniczy CRZZ, Warszawa 1979.

Polska Akademia Nauk - Komitet prognoz „Polska 2000 plus”, Polska w obliczu starzenia się społeczeństwa, Wydawnictwo Polskiej Akademii Nauk, Warszawa 2008.

Produktywność jako czynnik ksztattujacy wysokość wynagrodzenia, http://ciborowski.host247.pl/ wydajnosc.htm [dostęp: 26.04.2018].

Skirbekk V., Age and Individual Productivity: A Literature Survey, „Max Planck Institute for Demographic Research Working Paper" 2003, nr 23, s. 1-37.

Smith A., Badania nad natura i przyczynami bogactwa narodów, t. 1, Wydawnictwo Naukowe PWN, Warszawa 2012.

Społeczne konsekwencje starzenia się populacji ze szczególnym uwzględnieniem zmian relacji opiekuńczych, http://migageing.uw.edu.pl/wpcontent/uploads/sites/36/2015/01/SiM_03.pdf [dostęp: 26.04.2018].

Sytuacja demograficzna osób starszych i konsekwencje starzenia się ludności Polski w świetle prognozy na lata 2014-2050, http://stat.gov.pl/download/gfx/portalinformacyjny/pl/ defaultaktualnosci/5468/18/1/1/ludnosc_w_starszym_wieku.pdf [dostęp: 26.04.2018].

Why Business Should Recruit Young People, http://dera.ioe.ac.uk/13758/1/why-businesses-shouldrecruit-young-people.pdf [dostęp: 26.04.2018].

\section{Streszczenie}

Starzenie się osób pracujących to duży i globalny problem w czasach niskiego przyrostu naturalnego. Z powodu malejącej liczby urodzeń oraz wydłużania się czasu życia polskiego społeczeństwa dotyczy on również polskiej gospodarki. Jedną z ekonomicznych konsekwencji zjawiska starzenia się jest wydłużanie się aktywności zawodowej osób starszych. Z tego też powodu główny cel artykułu stanowi zbadanie kierunku oraz wpływu zmian struktury wieku osób pracujących na wzrost gospodarczy mierzony jako wydajność pracy (dynamika realnego PKB przypadającego na zatrudnionego). Wyniki przeprowadzonego badania empirycznego wykazały, że największą wydajnością pracy charakteryzują się pracownicy w wieku 40 lat. Wykazano także optymalne zróżnicowanie wieku pracowników, dla którego wydajność pracy jest najwyższa. Na podstawie otrzymanych rezultatów zaprezentowano możliwy ich wpływ na polską gospodarkę.

Słowa kluczowe: demografia, starzenie się społeczeństwa, wydajność pracy, struktura wieku osób pracujących, wzrost gospodarczy

Numer klasyfikacji JEL: J14, J20, C10, C20 